\title{
The Role of India and China in South Asia
}

\author{
BY CHRISTIAN WAGNER
}

India and China have a long and complex bilateral relationship that oscillates between concepts of "Chindia" and great power rivalry. In South Asia, India seems to be a regional power by default. But a closer look reveals that China is gaining an upper hand in the region. The analytical framework of the regional power debate helps to explain the different approaches between the two countries towards South Asia. Developments in the fields of politics, economics, and security indicate that India is at a structural disadvantage to China in the region.

\section{Christian Wagner, Senior Fellow} at the German Institute for International and Security Affairs (SWP), Berlin, explains that "In South Asia, India seems to be a regional power by default. But a closer look reveals that China is gaining an upper hand in the region."
The East-West Center promotes better relations and understanding among the people and nations of the United States, Asia, and the Pacific through cooperative study, research, and dialogue. Established by the US Congress in 1960, the Center serves as a resource for information and analysis on critical issues of common concern, bringing people together to exchange views, build expertise, and develop policy options.
Despite its superior material resources relative to other South Asian states, India has never managed to establish itself as a regional power. Attempts by Nehru and Indira Gandhi to portray the region as part of India's national security and to secure the country's foreign political interests through military, economic, and political interventions were mostly unsuccessful.

Several factors have always undermined India's regional power ambitions. First, because of the common religious, linguistic, and ethnic ties, foreign policy debates in the neighboring countries are often linked with debates about national identity which emphasize the distinctions from India. Hence, Indian interventions in the neighboring countries have often been perceived as threats to their respective national identities. In Sri Lanka, Buddhist nationalist groups have always been critical of India, in Bangladesh, the debate on Bengali and Bangladeshi nationalism is closely related with India, and in Nepal there is a controversy in most parties on the relations with the bigger neighbor to the South. The common religious, ethnic, and linguistic traditions that seem to bind the region have also acted as a counterbalance against India's regional ambitions.

Second, India has not pursued its foreign policy interests vis-à-vis its neighbors in a consistent manner, nor has it applied political, economic, and military capacities to achieve sustainable outcomes. The military victory over Pakistan in 1971 was not followed by a permanent settlement of the Kashmir issue. India supported Bangladesh after its independence in 1971 but could not prevent Bangladesh's economic and political realignment after the military coup in 1975. India's attempts to mediate in the Sri Lankan civil war in the late 1980s ended in political and military disaster. Finally, all neighbors have used the strategy of internationalizing their bilateral disputes with India, more or less successfully. Pakistan is the most obvious case, but Bangladesh, Nepal, and Sri Lanka have also played the "China card" at various times. foundation. Since then, South Asia is not only seen as an area of significance to India's 
"The Chinese infrastructure investments and security cooperation in the region have fostered apprehensions in India about encirclement by China."
The Asia Pacific Bulletin (APB) series is produced by the East-West Center in Washington.

APB Series Editor: Dr. Satu Limaye APB Series Coordinator: Peter Valente

The views expressed in this publication are those of the author and do not necessarily reflect the policy or position of the East-West Center or any organization with which the author is affiliated. national security, but also as a market that can contribute to India's economic development. The Gujral doctrine has emphasized the principle of non-reciprocity vis-à-vis India's smaller neighbors. The government of Prime Minister Manmohan Singh promoted bilateral and multilateral initiatives in order to provide regional public goods, like better connectivity and made unilateral economic concessions to the weaker states in order to expand intra-regional trade. India has also improved its security collaboration with most South Asian countries in recent years, except for Pakistan. This indicates that the threat perceptions among most South Asian governments have converged. The transnational networks of different militant groups are now seen as a common security challenge, leading to more cooperation among the security forces.

Despite India's changing South Asia policy, China has strengthened its position in the region. Politically, China has the advantage of being regarded as a "neutral" player in most South Asian countries, except for India. China has never been part of the discourse on nation-building in South Asia; therefore, China's bilateral relations with most countries of the region are not marred by the baggage of socio-cultural ties and previous interventions. Economically, China is also a more attractive partner for South Asian countries than India. The massive Chinese investment in India's neighborhood in the context of its "One Belt One Road (OBOR)" Initiative will increase Beijing's influence in South Asia. China has also expanded its trade relations and has surpassed India in some cases. Even in India, China has emerged as a significant economic actor. In the field of security, China has increased its military cooperation, supplying arms to many South Asian countries. The Chinese infrastructure investments and security cooperation in the region have fostered apprehensions in India about encirclement by China.

India seems to be caught in a catch-22 in South Asia. On the one hand, the religious, linguistic, and ethnic ties bind India with the region. On the other hand, those ties separate India from its neighbors with regard to nation-building. Such structural links, and their effects, are difficult to address. Hence, India will hardly be able to overcome resentments in the neighboring countries and to counter the advantages that China enjoys in many South Asia countries in politics, economics, and security. China remains an economically more attractive and politically more reliable partner for most of India's neighbors.

Despite their bilateral problems and tensions from respective engagement in South Asia, India and China have also increased their collaboration on the global level, for instance in the BRICS group (Brazil, Russia, India, China, South Africa). In the regional context, both countries are cooperating on initiatives like the Bangladesh-China-India -Myanmar corridor (BCIM), and China has also promised to make large scale infrastructure investment in India.

But these joint collaborations should not obscure the fact that India is structurally in a weaker position in South Asia compared to China. India is therefore losing its influence in South Asia vis-à-vis China. But it remains an open question how far the growing dependence on China will be a better deal for South Asian countries in the long term perspective. 